\title{
Justice in a One-Party African State: The Tanzanian Experience. A Rejoinder*
}

By Chris M. Peter

"Liberalism manifests itself in various ways.

To let things slide for the sake of peace and friendship when a person has clearly gone wrong, and to refrain from principled argument because he is an old acquaintance, a fellow townsman, a schoolmate, a close friend, a beloved one, an old colleague or old subordinate. Or to touch on the matter lightly instead of going into it thoroughly, so as to keep in good terms. The result is that both the organization and the individual are harmed. This is one type of liberalism."

Mao Tse Tung

\section{Introduction}

The article entitled "Justice in a One-Party African State: The Tanzanian Experience" by Professor Umesh Kumar of Faculty of Law, National University of Lesotho which appeared on 19 Verfassung und Recht in Ubersee (1986) p. 255 raises some fundamental issues which call for correction, clarification and comment. Due to the authoritative nature of the journal on Law and Politics in Africa, Asia and Latin America innocent and unsuspecting readers may end up quoting information which is not only incorrect, but also misleading. It is with the intention of avoiding such eventuality that we propose to make a short rejoinder to the article.

Let it be clearly stated right from the outset that we are in no way contesting Professor Kumar's conclusions on democracy in Tanzania and the implication of the one-party state on administration of justice. In our well considered opinion the very idea of one-party system has its roots in authoritarianism and is hence undemocratic. However, we arrive at this conclusion via a different method of analysis other than the Professor's

* The author would like to record his deep thanks to Mr. Rainer Bierwagen of the University of Konstanz, who provided recent materials on Constitutional development, Miss Ulrike Bühler, Konstanz and Mr. Sengondo Mvungi of the University of Dar es Salaam who commented on the draft.

1 Mao Tse Tung, "Combat Liberalism" Selected Works Volume II, Peking. Foreign Languages Press, 1967 pp. 31-33. Also reproduced in Tandon, $Y$. (ed.) Debate on Class, State and Imperialism, Dar es Salaam: Tanzania Publishing House, 1982 p. 14. 
static and ahistorical method which fails to mirror the political development in a socioeconomic and historical perspective. The rejoinder is divided into three main parts. In the first part which is fairly short, we indicate and correct factual mistakes. In the second part we pin-point misleading interpretations of documents, cases and events, and in the last part we make a comment on the one-party system in Tanzania and the Bill of Rights. It is our belief that these areas can only be understood if they are examined in a historical context.

\section{A. Factual Mistakes}

Here we intend to concentrate on major mistakes only, ignoring minor and inconsequential factual errors, which are not few. For purposes of clarity we propose to correct the mistakes seriatim (separately and in order). This is for a better and easier comprehension of the reader.

(i) Page 256 footnote no. 7. The author says that Tanzania was formed as a result of merger on 5th February, 1977 between what was once the Republic of Tanganyika and the Peoples' Republic of Zanzibar. That is incorrect. The fact is that the union between the two sovereign states was on 26th April, 1964. Tanganyika became independent on 9th December, 1961 and a year later became a republic. ${ }^{2}$ Zanzibar on the other hand attained its independence on 10th December, $1963 .^{3}$ On 12th January, 1964 there was a Revolution in Zanzibar which brought into power a revolutionary government. Less than four months after the revolution Zanzibar united with Tanganyika on the above given date to form the "United Republic of Tanganyika and Zanzibar". ${ }^{4}$ The Articles of the Union had already been signed four days earlier by the then President of Tanganyika Julius Karambage Nyerere and the late Sheikh Abeid Amani Karume the then President of Zanzibar and the chairman of the ruling Revolutionary Council. ${ }^{5}$ The Union was announced to the public on 26th April, 1964 after having being ratified by the Tanganyikan parliament and the Zanzibar Revolutionary Council. The name Tanzania came much later. A new name for the United Republic was adopted through an Act of Parliament in December, 1964. The new name is the United Republic of Tanzania. ${ }^{6}$ The Author therefore confuses the formation of the sole political party in Tanzania Chama Cha Mapinduzi (CCM) on the 5th February, 1977 (Following the merger of Tanganyika Press, 1965 p. 67.

4 See Union of Tanganjika and Zanzibar Act, 1964 (Act No. 22 of 1964).

5 The Articles of the Union are reproduced in Lofchie, Michael F., Zanzibar: Background to Revolution, Princeton: Princeton University Press, 1965 at p. 285.

6 See United Republic (Declaration of Name) Act, 1964 (Act No. 61 of 1964). 
African National Union (TANU) and Afro-Shirazi Party (ASP) with the Union between the two countries which was 13 years earlier. ${ }^{7}$

(ii) Page 266 footnote no. 56. The author writes "The Chief Justice of the Court of Appeal is appointed by the President". First of all such a post does not exist in the Tanzanian Judiciary. Secondly, the mistake here has legal and Constitutional implication. It assumes the presence of a Chief Justice for the Court of Appeal and another for the High Court. The Constitution of the United Republic of Tanzania provides for a Chief Justice of the High Court who is appointed by the President. ${ }^{8}$ The Court of Appeal of Tanzania was established by a separate Act of Parliament in 1979. ${ }^{9}$ The Chief Justice in his judicial capacity can only sit in the Court of Appeal and not in the High Court. However, in his administrative capacity he deals with matters concerning not only the Court of Appeal and the High Court but also all other lower courts. Jaji Kiongozi (and not Jaji Kiondozi) or Chief Judge is the principal assistant to the Chief Justice in his administrative capacity. As a judge he only sits in the High Court. ${ }^{10}$

(iii) Page 267 line 22. Here the author makes the following statement: "Only about a year before Juuyawatu's decision, there had been a circular from the Chief Justice of the High Court urging his colleagues, primarily in subordinate courts, to further the policies laid down by the party and the government". He then goes on to quote a reaction against that circular by the late Justice Biron. The above statement is incorrect both in reference to the time it was issued and the content of the circular. The alleged circular was issued by the former Chief Justice of Tanzania Honourable P.T. Georges in early 1973. And the quoted reaction by Justice Biron was during the Judges' and Magistrates' Conference held in Dar es Salaam in May, 1973. Ally Juuyawatu's case came 5 years later in 1978 and by then Tanzania had a new Chief Justice, Honourable Francis Nyalali. More important is the fact that that statement was not the subject-matter of the Chief Justice's circular. The statement is taken from a public speech made by the Chief Justice a year

7 On the birth of Chama cha Mapinduzi (CCM) See Herzog, Jürgen, Geschichte Tansanias, Berlin: VEB Deutscher Verlag der Wissenschaften, 1986 p. 240.

8 See Article 60(2) and Article 6l(1) of the Permanent Constitution of the United Republic of Tanzania. This Constitution which is only in Kiswahili has been translated into English by the United Kingdom Foreign Commonwealth Office and reproduced in Blausten, Albert P., and Flanz, Gisbert H., (eds.) Constitutions of the World Volume XVII, Dobbs Ferry, New York: Oceana Publications, Jul., 1979.

9 For a longer treatment of the Court of Appeal of Tanzania see Fimbo. G. Mgongo, "The Court of Appeal of Tanzania" (Mimeo.) Unpublished paper presented at the Faculty of Law. University of Dar-es-Salaam on 20th February, 1982.

10 See Seaton, E. E. and Warioba, J. S. "The Constitution of Tanzania: An Overview" Eastern Africa Law Review Volumes 11-14 (1978-1981) p. 35 at p. 60.

11 Proceedings of the 1973 Judges and Magistrates Conference. High Court of Tanzania, Unpublished. See also Wambali, M. K. B. and Peter, C. M. "The Socio-Economic and Political Context of the Judiciary: The Case of Tanzania" Unpublished paper presented at a Workshop on the Role of the Judiciary in Plural Societies held in Eldoret, Kenya between 30th January and 4th February, 1985. 
earlier and reported in the Daily News (Tanzania) of Tuesday 26th September 1972..2 The Circular by the former Chief Justice which came under attack at the Judges and Magistrates Conference had quite a different subject matter. It directed that all cases involving Ujamaa Villages should be sent directly to the Chief Justice because, according to the circular, he was the only person with jurisdiction to entertain such cases. Actually, in the same Conference, the late Justice of Appeal Yona Mwakasendo made it clear that until Parliament enacts law for the establishment of Ujamaa Villages, Judges and Magistrates would not heed to the Chief Justice's circular. In passing let us point out that even the citation of Ally Juuyawatus' case which appears on page 266 footnote 59 is incorrect. The correct citation of this case is 1979 Law Reports of Tanzania No. 6.

(IV) Page 270 footnote 70 . Here the author reports: "In this case, though the Regional Superintendent of Prisons had the detention order in his custody, he refused to accept the judicial summons to appear before the High Court with the detention order. Instead, he locked the document away and went away on a Safari. The High Court found this "disrespectful to the Court" but did not proceed in Contempt of Court. We would like to submit with all due respect that other than an attempt to over-dramatize the situation, nothing of the nature alleged by the author happened in the case of Ahmed Janmohamed Dhinani v. Republic of Tanzania. ${ }^{13}$ To prove our assertion we reproduce herunder a portion of the Judgment by the late Maganga, J.:

"... I am persuaded to agree that the Order under Section 2 of the Act which is under the hand of the Prime Minister and the Second-Vice President has been made pursuant to an order under the Hand of the President delegating the exercise of his executive powers under section 2 of the Preventive Detention Act, to the Prime Minister and the Second Vice President, either under section 9 (3) of the Constitution or under some other enabling legislation. For this reason I would rule that the Order produced before me is valid and therefore a lawful order". (emphasis added) ${ }^{14}$

By saying that the Order has been produced before him and that he was satisfied was the Judge cheating? Let it be pointed that over-dramatization may also lead to contempt of court.

\section{B. Misleading Interpretations}

(i) On pages 258 and 259 the author attempts to make a comparison between the development of the national movements into national parties in India and Tanzania. We

12 See "Put Mjamaa First" Daily News (Tanzania) Tuesday 26th September 1972 also quoted by James, R. W. "Implementing the Arusha Declaration. The Role of the Legal System" Dar es Salaam University Law Journal Volume 5 December, 1973.

13 (1979) Law Reports of Tanzania No. 1.

14 Ibid., This piece of Judgment is reproduced by Quigley, John, "Cases on Preventive Detention: A Review" Eastern Africa Law Review Volumes 11-14 (1978-1981) p. 326 at p. 341. 
find the comparison both ill-conceived and to a larger extent ahistorical. There are clearly visible differences between the two countries. Firstly, the charismatic leader in India, namely Mahatma Gandhi who had managed to unite the Indian people in the struggle against British colonialism never aspired for a public office. To the Indians, he was a father figure and that is why they admirably referred to him as "bapu" (father). ${ }^{15}$ Even at his death on 30th January, 1948, a few months after India's independence he was a private citizen. The charismatic leader in Tanzania, Julius Nyerere, managed to mobilize the people under TANU against the British and at Independence he assumed the highest office in the land. Ten years later in 1971 he was to tell the British Broadcasting Corporation (BBC) in an interview that "I have sufficient powers under the Constitution to be a dictator. «16

Secondly, religious squabbles which were threatening the two Countries at independence were handled quite differently and thus ended up producing different results. In India the conflict was between Hindu and Moslem. Various attempts were made to unite these two religious factions but all failed. A short time after the Simla Conference the leader of the Moslem League Mr. M.A. Jinnah requested the division of India into two separate countries. The British agreed to this on 3rd June, 1947 and thus creating Pakistan for the Muslims and India for the Hindus.

In Tanzania the Christian-Moslem problem surfaced in the late 1950s but was nipped in the bud. In 1959, some conservative muslim leaders in the coast operating through the All Muslim National Union of Tanganyika (AMNUT) proposed to the colonial government hat Tanganyka's independence should be delayed until Muslims achieved educational equality with Christians. ${ }^{18}$ It so happened that although Muslims are in majority the influence of the missionaries and the educational facilities they provided to their converts tilted the balance in the favour of Christians. At independence it was clear that they would occupy all the top and strategic bureaucratic positions in the government. This worried the Moslems and was the basis of their demand for the delay of independence so as consolidate themselves. However, TANU managed to mobilize some progressive Sheikhs to veto the proposal. In any case the fact that such a demand was ever made was an effective warning to the TANU government.

To quell a likely "Jihad" (a holy religious war), Nyerere wisely decided to democratically balance his government by ensuring that both religions were equally represented in the government and especially at the top level. Some leaders, who might have been

15 See Rudolph, Susanne Hoeber and Rudolph, Lloyd I., Ghandi: The Traditional Roots of Charisma, Chicago: The University of Chicago Press p. vii. See also Ashe, Geoffrey, Gandhi: A study in Revolution, London: Heinemann, 1968, and many other book on Gandhi and those by him.

16 See Hopkins, Raymond F., Political Roles in a new State: Tanzania's first decade, New Haven and London: Yale University Press, 1971 p. 26.

17 Gold, Gerald and Attenborough, Richard, Gandhi: Eine bebilderte Biographie, Bergisch Gladbach: BasteiVerlag Gustav H. Lübke GmbH \& Co, 1983 pp. 262-264.

18 See Iliffe, John, A Modern History of Tanganjika, Cambridge: Cambridge University Press, 1979 pp. 551-552. 
picked on religious grounds having had only a brief active career in the labour movement or in Show-business as film stars came to play an extremely important and progressive role in the early development of the young nation. They successfully spearheaded programmes on the Africanization of both the Civil and Political service within a short period which is something many African Countries have failed to achieve many years after independence. Their success led ambitious rivals to have no alternative other than resigning or running away to self-imposed exiles. ${ }^{19}$

In India it was not easy to achieve such a compromise. This explains why even today religion had developed into a serious political problem in that country. Currently, the Sikh are demanding for a separation from India and their struggle has also taken a religious dimension. ${ }^{20}$ The differences in the development of politics in the two countries is mainly attributable to the political maturity of the people themselves. In India the people were politicized much earlier and hence manipulation was not easier. In Tanzania, manipulation by those with political know-how was done without sophistry. This is because there was an alternative to persuasive method, namely detention. The Preventive Detention Act, 1962 was enacted only one year after independence to take care of potential dissent. And it did.

(ii) At p. 265 the author says that the Party's National Executive Committee (NEC) normally abides by the nominations made by the District Conference on the aspirants of the Parliamentary seats. Actually, the opposite is the case. To begin with, constitutionally, the NEC is not bound to follow that "normality". This departure is allowed by Article 27 (5) (b) of the Constitution which provides that:

"At the time of nominating candidates, the National Executive Committee shall not be compelled to follow the decision of the Annual General Meeting of the District as shall have been evidenced by the votes which have been cast by the delegates of that meeting."

Experience from both 1980 and 1985 General Elections indicate that the NEC uses its constitutional powers to pick extremely unpopular candidates provided that they have shown loyality to the party. It does not matter how sucha candidate has performed at District level. These powers are also used to bar popular candidates who in the past parliament have been vocal or critical to government policies. Critical characters who are already known to the party and government are barred from joining the Parliament through a rigorous use of this provision of the Constitution. An example of practical application of the powers of the NEC is the case of Wolfgang Dourado of Zanzibar in the 1985 General Elections. Dourado, a former Attorney-General of Zanzibar and a seasoned government critic was aspiring to join the House of Representatives (which is

19 See Mazrui, A. A. "Heroic Yes, Successful No." Africa Events (London) May/June, 1986 p. 62 . See also Hopkins, Raymond F., "The Role of the M.P. in Tanzania" The American Political Science Review Volume 64 No. 3 September 1970 p. 754 at p. 769.

20 See "Punjab’s Bloody Hand" Time Magazine (USA) 15th December, 1986 p. 24. 
the Parliament in Zanzibar). He was contesting in the Raha Leo Constituency. At the District Conference he scored the highest preferential votes ever - $95 \%$. The NEC axed his name nevertheless. Why? Because in the view of the party he was anti-union and contributed to the "pollution of the political climate" in 1983 which led to the fall from power of the Second President of Zanzibar Sheikh Aboud Jumbe Mwinyi. ${ }^{21}$ Dourado wrote a long letter of protest to the Chairman of the Party Julius Neyerere in November, 1985 expressing his grievances. Up to now this letter which raises fundamental democratic and constitutional issues has not been answered. ${ }^{22}$ There are many other known but unrecorded cases of candidates whose candidacies were aborted by the NEC.

(iii) On page 272 the author makes reference to the effect that Tanzania is a signatory both to the United Nations Declaration on Human Rights of 1948 and the Organisation of African Unity's African Charter on Human and Peoples' Rights and therefore may feel obligated to respect Human Rights. The idea is attractive but divorced from reality in the world and pegged in idealism. By the way, let it be pointed out that in 1948 when the Human Rights Declaration was adopted unanimously by the General Assembly it was not opened for signature like the normal conventions which are aimed at creating new norms of international law. The Declaration was an amplification of the many articles on Human Rights which were scattered in the UN Charter itself. ${ }^{23}$

Important developments followed the preparation of three new convenants which have been adopted by the General Assembly and they are now in force. These are the International Covenant on Economic, Social and Cultural Rights which entered into force on 3rd January, 1976; the International Covenant on Civil and Political Rights which came into force on 23rd March, 1976; and the Optional Protocol to the International Covenant on Civil and Political Rights which also entered into force on 23rd March, 1976. The three documents are open to signature and Tanzania is a signatory to the first two instruments but not to the third. ${ }^{24}$ The major difference between the first two covenants and the Optional Protocol is that the Optional Protocol provides an Individual, who is a

21 The Events leading to the resignation of the 2nd President of Zanzibar Sheikh Aboud Jumbe Mwinyi remains unclear up to to-day. This is mainly because NEC's sessions are held in Camera. All what was reported was that in a long session in early 1984, the NEC dealt with issues related to the pollution of the political climate and then that the President of Zanzibar has stepped down relinquishing all his party and government positions. There are unconfirmed allegations that he and his legal advisers were preparing a Constitutional Case against the United Republic in accordance with the provisions of part 6 of the Constitution which provides for a Special Constitutional Court. On this whole issue see Versi, Anver, "Zanzibar in turmoil" New African (London) March, 1984 p. 19.

22 Dourado's letter is reproduced in African Events (London) November, 1985 p. 28. See also Rajab, Ahmed "Foul Play" on the same page.

23 See UN Secretariat, UN Yearbook on Human Rights for 1949, Millwood, New York: Klaus Reprint Co., 1973 p. 327.

24 See UN Secretariat, UN Yearbook on Human Rights for 1977-1978, New York: United Nations, 1982 p. 257. A breakdown of Tanzania's performance with respect to 29 main articles of the 1948 Universal Declaration on Human Rights ont of the 30 articles that make the Declaration see the same book on pages $162-168$. 
victim of Human Rights violation locus standi to proceed in his own capacity to present his case by the way of a petition to the Human Rights Committee. ${ }^{25}$ The victim does not require the support of his state in prosecution of his violated rights.

The OAU's African Charter on Human and People' Rights which was adopted at the Nairobi Summit in 1981 is an important document especially in a continent with a widespread disregard and violation of Human Rights. ${ }^{26}$ It entered into force recently. ${ }^{27}$ It is the hope of the International Community that the states will not take advantage of some of the loose provisions in the Charter in order to further fascist measures. ${ }^{28}$

\section{Comment}

There are a cluster of issues scattered throughout the article which also call for a reply. However because they are eclectically presented it is not easy for us to pursue one after the other as was the case of factual mistakes and misleading interpretations. Issues like party supremacy being a political or a legal fact have long been settled and it makes little sense to labour on them. Also it is hairsplitting to engage in arguments on which party decisions are supreme. The party Constitution is very clear on its supervisory role to the government and other state organs. In order to understand the political set-up in Tanzania, there is a need of tracing the development of the consolidation of the party to the present systematically. In our comment we intend to do that so as to place issues in context as a political system is not built in a day. In the end we also intend to place the issue of Bill of Rights in its historical setting because in our opinion, the Bill of Rights was not introduced by those in power in order to check their excesses but it was the result of the peoples struggle to regain their lost freedom.

25 According to Articles 28 and 29 of the International Covenant on Civil and Political Rights, the Human Rights Committee Consists of 18 members, national of States party to the Covenant, who are persons of high moral character and of recognized Competence in the field of Human Rights. These persons are elected by a meeting of States party to the Covenant from the list of persons nominated by those states. The system of presenting claims under the Optimal Protocol is described by Tardu, Maxime E., Human Rights: The International Petition System (Binder I) Dobbs Ferry, New York: Oceana Publications, Inc., 1979 at p. 15.

26 The African Charter in Human and Peoples' Rights is reproduced in Kunig, Philip; Benedek, Wolfgang; and Mahalu, Costa Ricky, Regional Protection of Human Rights by International Law: The Emerging African System. Baden-Baden: Nomos Verlagsgesellschaft, 1985 at p. 95 . It is also discussed at length in Welch, Claude E and Meltzer, Ronald I., Human Right and Development in Africa, Albany, New York: State University of New York Press, 1984.

27 See "African Charter in Force" Amnesty International Newsletter Volume XVI No. 12 December, 1986 p. 1.

28 See for Instance Article 6 which provides in part that ". . No one may be deprived of his freedom except for reasons and conditions previoursly laid down by law . . " This may be interpreted to mean that where a state already has a law on detention (and the majority of African states already haoe) then not withstanding the provisions of the Charter, they may go ahead and detain people and that wont amont to a violation of the Charter. 
Consolidation of the power of the party in Tanzania was not a smooth and peaceful affair. It entailed political battles with many casualities, some ending in detention, internal deportation and others in exile. Due to the opposition to the idea, the whole process was accomplished strategically, systematically and in calculated phases. First, the one-party system was decreed and thereafter the sole party was declared supreme. At Independence Tanzania (then Tanganyika) was a multi-party state. After independence many more new political parties were registered. Therefore apart from TANU which was dominant the other parties were the United Tanganyika Party (UTP) formed in 1958; and the African National Congress (ANC) also formed in 1958. Other parties that emerged after 1962 include the Peoples Democratic Party (PDP) led by Kasanga Tumbo; the Peoples Convention Party (PCP) led by Samson Mshala; the Nationalist Enterprise Party (NEP) established by Hussein Yahaya; All Muslim Nationalist Union of Tanganyika (AMNUT); and African Independence Movement (AIM) which was a merger between Mshala's PCP and Yahaya's NEP. ${ }^{29}$

It may therefore be misleading to say that there was no perceptible opposition to TANU. There were also reports of some TANU members resigning and joining the new emerging parties. One reported case is that of Chief Masanja who resigned to joint the ANC in $1962 .{ }^{30}$ In this period there was total agreement that the parliament was supreme. The former President of Tanganyika and President of TANU as well drew attention to this fact. In his speech on 25th April, 1964 to the National Assembly asking it to ratify the Union between Tanganyika and Zanzibar he said:

"This Parliament is the Supreme Organ of the People of Tanganyika. No important constitutional issues or important matter concerning state agreement or concerning the laws of this country, can be finally decided by anyone or any group of persons other than this Assembly. All such matters must be brought before this house, and it is entirely at your discretion to approve them or reject them. Today, I am submitting to you for consideration a draft agreement for the Union of Tanganyika and Zanzibar" (emphasis added). ${ }^{31}$

Thus, in order to depart from this position of parliamentary supremacy towards party supremacy, TANU and its government had to take care of the other parties. The first step was to retain TANU as the sole political party in the country. To fulfill this end, the government undertook a systematic intimidation of the leadership of the opposition with an aim of suffocating their parties. Cranford Pratt, a Canadian political scientist who

29 These parties have been discussed at length in Mlimuka, A. K. L. T. and Kabudi, P. T. A. M. "The State and the Party" in Shiwi, Issa G., The State and the Working People in Tanzania, Dakar, Senegal: Codesria Book Series, 1985 p. 57 at p. 62.

30 See Hopkins, Raymond F. "The Role of the M.P. in Tanzania" op. cit. at p. 755 footnote 8.

31 See Parliamentary Debates (Hansard) 25th April, 1965 Col. 1 quoted by Msekwa, Pius, Towards Party Supremacy, Arusha: Eastern Africa Publications Limited, 1977 p. 22. 
has spent a large portion of his academic career studying Nyerere and his philosophy recounts that:

"In Tanzania the several tiny parties which appeared in 1962 were harassed out of existence, their leadership deported of detained and their rights to register and to hold meetings severely restricted. ${ }^{32}$

Having forcefully pushed the oppositon out of existence through its government, TANU went ahead to propose itself within itself the only political party in Tanzania.

The first proposal came from the party President to the TANU National Conference in 1963. He argued in the following lines:

"Where there is one party, and that party is identified with a nation as a whole, the foundations of democracy are firmer than they can ever be where you have two or more parties, each representing only a section of the community. " $^{33}$

In the same year the Party's National Executive Committee (NEC) made the decision to turn Tanganyika into One-party State. Therefore, when the President was briefing the Commission he had set, as instructed by NEC, on the establishment of a democratic one-party state he reminded this Commission of the extent of its mandate:

"In order to avoid misunderstanding, I think I should emphasize that it is not the task of the Commission to consider whether Tanganyika should be a one-party state. The decision has already been taken. Their task is to say what kind of one party state we should have in the context of our own national ethic and in accordance with the principles I have instructed the Commission to observe. ${ }^{34}$ (emphasis added)

The party which was (and still is) in minority in comparison with the total population of the country had taken on itself the task of dictating what should be done. The people were being faced with a fait accompli. An important matter like this ought to have been subjected to a referendum so that all people could democratically participate.

Tanzania was formally declared a one-party State with the Interim Constitution of Tanzania, 1965. Article 3 (1) of this Constitution declared in no uncertain terms that "there shall be one political party in Tanzania". The Constitution in the same Article went on to acknowledge the fact that there were two political parties in Tanzania. Therefore, one-political party actually meant two political parties. That is, TANU in the mainland and Afro-Shirazi Party in Zanzibar. This set-up was to continue for the next 12 years until their merger on 5th February, 1977 to form Chama Cha Mapinduzi (CCM).

Having established the one-party system, the next step was to strive for party supremacy. It should be noted that one-party system does not necessarily imply that the party is

32 Pratt, C. The Critical Phase in Tanzania 1945-1966: Nyerere and the Emergence of Socialist Strateg. Cambridge: Cambridge University Press, 1974 p. 187.

33 Nyerere, Julius Kambarage, Freedom and Unity, Dar es Salaam: Oxford University Press, 1966 p. 196.

34 See Report of the Presidential Commission on the Establishment of a Democratic One-Party State. Dar es Salaam: Government Printer, 1968 p. 2 paragraph 8. 
supreme. ${ }^{35}$ The notion of party supremacy was a novel invention by Tanzania. Research indicates that even in Communist countries the party is not supreme. ${ }^{36}$

Therefore, there were still hopes that even within a one-party system parliamentary supremacy would be retained. The party had other ideas - to declare itself supreme. There followed a tug of war between those in support of parliamentary supremacy and those attempting to pave way for party supremacy.

The party leadership seized every opportunity available to hammer home the importance of party supremacy. For example, when conveying fraternal greetings to the conference of the now defunct Uganda People's Congress (UPC) on 7th June, 1968 the President of TANU argued a case for TANU's supremacy. He was very clear:

"For the truth is that it is not the party which is the instrument of the government. It is the government which is the instrument through which the party tries to implement the wishes of the people and serve their interests. ${ }^{37}$.

The party leadership had an advantage in that it had control also of the government. It therefore had control not only of the ideological state apparatus but also of the coercive state apparatus. It was the same people making decisions in the party and the government. Therefore, the issue was the label which a decision is given. Either a party decision or a government decision - but in reality it was the same people involved. The party singled out the parliament as a source of problems and made it a policy to ignore it in all major decisions affecting the welfare of the country as a whole. Among these decisions is the one to nationalize all major foreign private investments in the country following the Arusha Declaration of 1967 made by the party. It was at this point in time that the question of supremacy surfaced.

In the June/July 1967 Budget session, a question by the member of parliament for Musoma North Mr. P. T. Ndobho appeared on the order Paper calling upon the government to clear the dust over the supremacy issue between the party and the National Assembly. ${ }^{38}$ The government played down the question. However, the MPs were determined to iron out issues and assert the supremacy of the Parliament. Contributing to the debate on the Interim Constitution of Tanzania (Amendment) Bill the

35 Actually back in 1966 after the adoption of the Interim Constitution which declared Tanzania a One-party state, the former Chief Justice P. T. Georges made the observation that the Constitution does not set the party above the organs of the State. See. Georges, P. T., "The Court in the Tanzania One Party State" in Sawyer, G. F. A. (ed.) East African Law and Social Change, Nairobi: East African Publishing House, 1967 p. 26 at p. 29. He is also quoted by Fimbo, G. Mgongo, "Land, Socialism and the Law in Tanzania" Eastern African Law Review Volume 6 No. 3 (1973) p. 215.

36 See Ng'maryo, Eric Sikujua and Mawalla, T.R.W.S. "Strengthening the Power of the People" Unpublished paper presented at the Tanganyika Law Society Seminar on the proposed Constitutional Changes held in Dar es Salaam in July, 1983.

37 See Nyerere, Julius Kambarage, "The Party Must speak for the People" in Nyerere, J. K. Freedom and Development, Dar es Salaam: Oxford University Press, 1973 p. 30 at pp. 32-33.

38 Parliamentary Debates (Hansard) $18^{\text {th }}$ July, 1967 Question No. 500 quoted in Mwakyembe, Harrison George, "The Parliament and the Electoral Process" in Shivji, Issa G.. (d.) The State and the Working People in Tanzania, op. cit. p. 16 at p. 41. 
member of parliament for the Iringa South Mr. M. Chogga made the proposal to the effect that the Constitution should be amended to make the parliament adviser to the president of the United Republic and that matters discussed by other organs such as TANU and or the Cabinet should ultimately be submitted to the parliament for final approval or other action. The then Second Vice-President Rashid Kawawa reacted sharply to Mr. Chogga's comments and said that to his understanding of the Constitution Afro-Chirazi and TANU were supreme. ${ }^{39}$

The debate did not end there. In the following year it was again on the agenda. Debating a Bill to increase the number of Constituency members of the parliament from 107 to 120 in October, 1968, two members Mr. Masha and Mr. Mwakitwange argued that in the post-Ansha era the role and the status of the parliament seemed confused and needed clarification from the government before additional expenses were incurred in enlarging that institution by increasing the number of members as was now being proposed. This was a valid concern as there was no point increasing expenses to run a rubber-stamping institution. The then Parliamentary Secretary in the office of the Second Vice-President Mr. Richard Wambura intervened:

"Mr. Speaker, I want to make it clear that it is the party which is supreme and all the MPs are expected to work under the leadership and guidance of the party. The party picked you MPs in nomination and the party has the right to discipline you and dictate your tasks. It is high time that the MPs should know where they come from, and it is beyond any doubt that this parliament belongs to TANU. ${ }^{40}$

Notwithstanding Wambura's statement, querries continued. It was at this point that the then Second Vice-President Kawawa, who was also then the leader of the governement business in the House rose to reply. He repeated an old story:

"TANU and ASP are the originators of this state. The two parties are policy makers while the duty of the government is to implement the policies. We have assisted the government with parliament, law and finance to facilitate such implementation ... we are governed mentally by our colonial past in believing that the government is supreme. The German and British impact is still with us. We need to bring about our mental revolution to remedy this situation ... In a one-party democracy the party is supreme all the way. ${ }^{41}$

At this point the parliament got divided. For opportunist characters in parliament the time to capitulate had arrived. To save their skins they chose the side of the stronger and deserted the struggle for democracy. It was in this period that we get members like one Mrs. Baraka suggesting in the House that if the government had no confidence in an MP

39 See Msekwa, Pius, Towards Party Supremacy, op. cit., p. 41.

40 Parliamentary Debates (Hansard) ${ }^{\text {st }}$ October, 1968 Col. 23 quoted by Msekwa. Towards Party Supremacy. op. cit. p. 47.

41 Parliamentary Debates (Hansard) 1st October, 1968 Col. 47-48 quoted by Srivastava, B. P. "The Constitution of the United Republic of Tanzania 1977 - Some Salient Features-Some Riddles" Eastern Africa Law Review Volumes 11-14 (1978-1981) p. 73 at p. 110. 
it should sack him. ${ }^{42}$ This was a suggestion based on ignorance of both the law and procedure governing the parliament. It nevertheless won her party support. More to the point was MP Ali Migeyo who called upon the party to wipe out counter-revolutionary elements. ${ }^{43}$ The final to this duel was not far. The Party's NEC meeting in Tanga in October, 1968 dropped the sword. Seven MPs were expelled from the party for whaving grossly violated the party creed both in their attitude and actions and for showing a very clear opposition to the party and its policies. ${ }^{44}$ The expulsion had far reaching consequences. It carried with it automatic loss of the title to a parliamentary seat. All the vocal MPs were therefore ousted. This action by the party was defended by a member of the House, one Crisant Mzindakaya who declared that the party had the right to dismiss members who turned out to be "unfit". ${ }^{45}$ Helge Kjekshus analyses at length this hectic period of the Tanzanian parliament and records the way disagreements were muffled in search of compromise and accomodation. ${ }^{46}$

From then on the parliament became a non-issue. It was retained as an expensive rubber-stamping machinery used as a show-piece to the international community as an indicator of democracy in Tanzania. Any attempt to re-assert its proper role has been handled high handedly. For instance in 1973 the majority of MPs opposed the Income Tax Bill. The Bill was proposing to increase income tax and do away with children and marriage allowances on the pretext that the allowances benefitted only as small portion of the population. The merits and demerits of the Bill are not our concern. What is interesting is the way the president handed the whole issue. He called a press conference and threatened to dissolve the parliament. He gave the MPs one month to go and think about the Bill. After one month every MP came praising the Bill. ${ }^{47}$ The threat had its effect.

It should be remembered that up to this point there was nothing on legislation on party supremacy. This situation created a new and unexpected problem, namely the enforcement of party directives in the courts of law. Judges and Magistrates are required to administer justice according to the law as enacted by parliament and not the NEC directives. This situation created crisis arising out of the 1973/74 villagerization programme in which at times excessive force was used. There arose claims and counterclaims over ownership of property especially land between individuals and villages. In most cases the villages lost because they had no legal basis. It was an embarrassing situation which led not only to legislation of the villages but also of the party supremacy.

42 See the Nationalist (Dar es Salaam) $2^{\text {nd }}$ October, 1968.

43 Ibid.

44 See Msekwa, Pius, Towards Party Supremacy op. cit. p. 48.

45 Parliamentary Debates (Hansard) $25^{\text {th }}$ March, 1969 Col. 19-20 quoted by Mwakyembe, Harrison George, "The Parliament and the Electoral Process" op. cit. at p. 44.

46 Kjekhus, Helge 'Parliament in a One-Party-State - The Bunge of Tanzania 1965-1970 Journal of Modern African Studies Volume 12 (1974) p. 28.

47 See Uhuru (Dar es Salaam) 28th November, 1973 quoted by Mwakyembe, Harrison George, "the Parliament and the Electoral Process", op. cit. at p. 44. 
Party Supremacy was entrenched officially in the Constitution in 1975 through Act number 8 of 1975 which amended section 3 of the Interim Constitution, 1965. The Amendment provides that:

"All political activities in Tanzania shall be conducted by or under the auspices of the Party."

and further that:

"The functions of all the organs of the state of the United Republic of Tanzania shall be performed under the auspieces of the Party."

This amendment has been incorporated in the 1977 Permanent Constitution of the United Republic of Tanzania which declares Chama Cha Mapinduzi the only political party in the Country. The Constitution goes further than declaring the party supreme. It reduces the parliament to a mere committee of the National Conference of the Party with the duty of implementing party policies. ${ }^{48}$ Harrison Mwakyembe correctly observes that with the adoption of the 1977 Permanent Constitution the parliament remained without any significant role and its function became that of acting as a sounding board and a forum for applauding and legitimizing new party policies. ${ }^{49}$ To concretize his point he quotes the example of former president Nyerere's New Year Message broadcast live by Radio Tanzania on 31st December, 1982. Announcing new taxes to the public, Nyerere said:

"You will aready have heard of the new taxes which come into force tomorrow, the first of January, 1983. These tax measures will be debated in parliament in its next sitting, but in the meantime they have to be paid by everyone. "50 (emphasis added). The President, who is also the party Chairman knew what he was talking about. The parliament can discuss the taxes, praise them or condemn them, but at the end of the day it will endorse the new taxes. Such an assured stance does not only originate from party supremacy, but also from the fact that numerically the government appointees in the parliament are in majority. $53 \%$ of the members of parliament are appointees of the Executive and the remaining $47 \%$ directly elected by the people. In other words in a parliament of 238 members, 127 are appointed by the Executive and 111 elected in the constituencies. Therefore, it is practically impossible to defeat a government Bill in House, unless many MPs among those indirectly appointed by the Executive are absent. Therefore, the best the MPs can do is to delay the passing of a Bill but not to block it. ${ }^{51}$ The Parliament has its parallel in the National Executive Committee of the Party (NEC). Act 49 of 1965 provides this body with tremendous powers. The members of this

48 See Article 54 (I) of the Permanent Constitution of the United Republic of Tanzania, 1977 which has to be read tugether with Section 59(II) of the Chama Cha Mapinduzi (CCM) Constution of 1977.

49 Mwakl'mbe. Harrison George, "The Parliament and the Electoral Process", op. cit. at p. 45.

50 Ibid., See also Daily News (Dar es Salaam) I ${ }^{\text {st }}$ January, 1983.

51 On the breakdown of the membership to the National Assembly See Shivti. Issa G., "The state of the Constitution and the Constitution of the State in Tanzania" Eastern Africa Law Review Volumes 11-14 (1978-1981) p. 1 at p. 27.; and Mlawa, George F., "The Constitution of the United Republic of Tanzania: Proposed Changes" Eastern Africa Law Review Volumes 11-14 (1978-1981) p. 128 at p. 160. 
Committee are paid the same salaries and allowances as parliamentarians, and the Committee can summon witnesses, call for documents to be produced before it. It is an offence to disobey the orders of the NEC, to refuse to appear before it or to present fake or fabricated documents with an intention to deceive it. It is for all intents and purposes a parliament, only that it is not elected by the people of Tanzania as a whole.

\section{(ii) The Bill of Rights in Tanzania}

The Bill of Rights has been historically linked to concepts like rule of law, Independence of the Judiciary, Supremacy of Parliament and Separation of powers. These were the pillars of the French Revolution of 1789. They are also identified with democracy. In Tanzania, the history of Bill of Rights is long and it did not begin in 1984. It is a history of the attempt by the people to consolidate their independence from colonial rule and frustration of the same. The presence of a Bill of Rights in the Constitution would have been a check to the many undemocratic decisions made in the early period of Independence. For instance, it would have been impossible to declare a one-party system because that would amount to an infringement of the peoples' right to organize. It is both strange and laughable to talk of democracy in a one-party state. Honourable P. T. Georges has correctly observed that:

"It is difficult to separate the ideas of one-party rule and of authoritarianism and restrictions on human liberty. There can be no doubt that one-party state does impose a restriction on the freedom of the individual to propagate his views and beliefs by means of forming and promoting political parties. ${ }^{52}$

It is our submission that absence of a Bill of Rights is a sine qua non for the smooth functioning of a one-party system. That means an undemocratic regime can freely do whatever it likes without the people having opportunity to contribute to issues concerning their very welfare. That is actually what has been taking place in Tanzania.

It is therefore not an accident that a Bill of Rights comes 23 years after Independence. There was a systematic attempt to ensure that each and every kind of opposition is effectively controlled. It is not surprising that even the current Bill of Rights which comes into effect in 1988 is surrounded with ambiguity. A short survey of the history of Bill of Rights in Tanzania will contribute to the better understanding of political and constitutional development in the country.

During the negotiations for Independence between the nationalists and the British government there was a long debate over the inclusion of a Bill of Rights in the Independence Constitution. For the British it was a custom that every colony moving to Independence had to entrench a Bill of Rights in its Constitution. Read records that by 1973 about 32 of the former British colonies had Bills of Rights. ${ }^{53}$

52 Georges, P. T., "The Court in the Tanzania One-Party State" in Sawyer, G. F. A. (ed.) East African Law and Social Change, Nairobi: East African Publishing Horue, 1967 p. 26 at p. 27.

53 Read, James $S$., "Bills of Rights in the Third World" Some Commonwealth Experiences" Verfassung und Recht in Ubersee 6. Jahrgang (1973) p. 21. 
It should be clearly stated that the British were not so much worried about the freedoms and the democratic rights of the indigenous people in the former colonies. Their primary concern was the fate and the property of the British nationals, who had invested heavily in the colonies and could not leave immediately. These subjects of the crown required protection and constitutional safegards. The nationalists led by TANU made two arguments. First, that they were in a hurry to build the country and that such a Bill of Rights would stand as a hinderance. Second, that the judiciary in the country was still manned by expatriates - mainly whites, who would take advantage of presence of such a Bill to frustrate the new governement by declaring many of its actions illegal. The Bill of Rights was therefore shelved.

The matter was raised again in 1962 in the proposal for a republic. The government categorically said that it believed that rule of law was best preserved not by formal guarantees in a Bill of Rights which invited conflict between the Executive and the Judiciary but by independent judges administering justice free from political pressure. The people were slowly maturing politically. In the debate for the establishment of one-party state proposals were made for inclusion of a Bill of Rights in the Constitution. One such proposal was presented to the Presidential Commission on the Establishment of a Democratic One-Party State by the Tanganyika Law Society (which is a society of practising lawyers). This proposal noted inter alia that it was incorporating a guarantee of these rights in the constitution that it could ensure universal respect. The proposal by the lawyers was conveniently ignored by the government.

Instead, these fundamental rights were presented in a general form in the preamble to the constitution. This was not done blindly. The government might have been well advised. The preamble is legally not part of the Constitution under the common law system and hence one could not base a case on it. The status of the preamble is well explained by Justice of Appeal Kisanga in his separate judgment in ATTORNEYGENERAL V. LESINOI NDEINAI AND TWO OTHERS. ${ }^{44}$ The judge said that the preamble was:

"a declaration of our belief in those rights. It is no more than just that. The rights themselves do not become enacted thereby such that they could be enforced under the constitution. In other words one cannot bring a complaint under the constitution in respect of violation of any of those rights as enumerated in the preamble."

Before 1977 , one could enforce these rights by going around the restriction. This means, in the Interim Constitution of 1965, the TANU Constitution was appended as the first Schedule to the Constitution. The TANU Constitution contained individual guarantees similar to those provided for in the preamble. Therefore one could successfully protest

54 See the hon. the Attorney-General, Appellant V. Lesinoi Ndeinai, Joseph Saleyo Laizer, Masai Lekasi, and Omar Jamaluddin Ukaye, Respondents, Court of Appeal of Tanzania at Arusha, Criminal Appeal No. 52 of 1979 and Criminal Appeal No. 53 of $1979,23^{\text {rd }}$ July, 1980. This Case is treated at length by Professor Quigley in Quigley, John "Cases on Preventive Detention: A Review" Eastern Africa Law Review Volumes 11-14 (1978-1981) p. 326. On an earlier division on status of the preamble see Hatimali Adamti V. E.A.P.\& T. Corporation (1973) Law Reports of Tanzania No. 6. 
against violation of his rights through the Schedule to the Constitution, which unlike the preamble, is part of the constitution and on which claims can be based on it. A successful trial of using the Schedule was done in the 1973 case of THABIT NGAKA V. REGIONAL FISHERIES OFFICER (Morogoro). ${ }^{55}$ However, that is history now as the 1977 Constitution of the United Republic does not contain party constitution as a schedule. As usual, the proposals to amend the Constitution leading to the 1984 amendments came from the party. The proposals were not general. The NEC specifically pin-pointed the areas of the Constitution which the party wanted amended. The areas were grouped as follows: The powers of the president; consolidation of the authority of the parliament; strengthening of the representative character of the National Assembly; the consolidation of the Union; and the consolidation of the Peoples' power ${ }^{56}$ As seen from above proposals, a Bill of Rights was not contemplated by the party. It was rather a demand by the people. The pressure was ultimately so great that the party had to concede. But what a Bill of Rights!

The 1984 Bill of Rights was introduced into the Constitution vide the Fifth Constitutional Amendment Act, 1984. ${ }^{57}$ This has to be read together with the Constitution (consequential, transitional and temporary provisions) Act, 1984. ${ }^{58}$ There are two remarks to make on this Bill of Rights. Firstly, the Bill does not come into effect with the other amendments to the Constitution immediately after assent by the president and publication in the official gazette. Section 3 (2) of the Constitution (Consequential, Transitional and Temporary Provisions) Act, 1984 provides that:

"Notwithstanding the amendment of the Constitution and, in particular the justifiability of the Provisions relating to basic rights, freedoms and duties, no existing law or any provision in any existing law may, until and after three years from the commencement of the Act, be construed by any court in the United Republic as being unconstitutional or otherwise inconsistent with any provision of the constitution" (emphasis added).

The amendments to the constitution came into affect on 15th March, 1985 when they were published in the official Gazette. That means, the Bill of Rights will come into operation on 15th March, 1988. The question is whether this was necessary.

The Chief Justice of Tanzania Hon. Francis Nyalali argues that that period was meant to provide the government with time to put its house in order by reforming all the laws which are inconsistent with the Bill of Rights. ${ }^{59}$ That argument is not unpersuasive because there exists a mass of legislation, some enacted during the colonial era and

55 (1973) Law Reports of Tanzania No. 24.

56 See Chama Cha Rapinduzi Department of Propaganda and Thass Mobilization, 1983 "Proposals for Changes in the Constitution of the United Republic and the Constitution of the Revolutionary government of Zanzibar" Nec, Dodoma, Tanzania.

57 Act No. 15 of 1984.

58 Act No. 16 of 1984.

59 Nyalali, Francis, C. J., "The Bill of Rights in Tanzania", A Public Lecture delivered at the Faculty of Law, University of Dar es Salaam on $5^{\text {th }}$ September, 1985 (unpublished.) 
inherited by independent government which curtail and infringe on the rights of the individual. Some of these laws have to be completely repealed or amended to be consistent with the letter and the spirit of the new Bill of Rights. These oppressive laws include the Preventive Detention Act, 1962; the Deportation Ordinance, 1921 (Cap. 38); Resettlement of offenders Act, 1969; Regions and Regional Commissioners Act, 1962 (Cap. 461); the Area Commissioners Act, 1962 (Cap. 466); Explusion of undesirables, 1930 (Cap. 39); Human Resources Deployment Act, 1983; Peoples Militia (Powers of Arrest) Act, 1975 and many others. ${ }^{60}$ Also to be taken care of are the oppressive By-laws made by the mushrooming city and town councils after the reintroduction of the local government in $1982 .{ }^{61}$ It is hoped that the government and in particular the Law Reform Commission will meet the set deadline.

The second remark concerns restriction of rights within the Bill of Rights itself. Problematic is Article 17 (2) (a). This article exempts any lawful action which seeks to restrict the basic right to freedom of movement from the general prohibition against violation of that basic right. This exemption waters down the whole right to free movement. The right is given and then immediately taken away. Much will depend on how the courts will interprete the contents of this Article in practice.

An interisting Article which might lead to debate is that on the basic right of freedom of association. This Article 20 (I)provides that:

"Every person shall be entitled to be free,

according to law, to assemble freely and

peacefully, to associate with others, to hold

and express opinions publicly, and in particular

to form or join organizations or associations for the

purposes of promoting his or her opinions or interests."

People are bound to ask whether the freedom of association provided for in this article encompass freedom to form political parties in a one-party State.

\section{Conclusion}

By the way of conclusion we would like to submit that a clear comprehension of the political set up in Tanzania entails first and foremost an examination of the class set-up in the country. Otherwise intra-class squabbles might be magnified beyond proportion

60 These laws are discussed by Shioji, Issa G., "The state of the Constitution and the Constitution of the State in Tanzania" op.cit. at. p. 15; Shaidi, L. P., "Tanzania: The Human Resources Deployment Act, 1983 - A Desperate Measure to Contain a Desperate Situation", Review of African Political Economy. No. 31 December, 1984 p. 82.; Legal aid Committee, Faculty of Law, University of Dar es Salaam, Essays on Law and Society, Kampala: Sapoba Bookshop Press Limited, 1985; and Martin Robert, Personal Freedom and the Law in Tanzania, Nairobi: Oxford University Press, 1974.

61 See Local Government (District Authorities) Act, 1982, No. 7 and Local Government (Urban Authorities) Act, 1982, No. 8 of 1982. 
and thus hide the real conflicting class interests. Class struggle manifests itself in various forms including law and its administration. Writing back in 1966, former Chief Justice Georges argued that the one-party-system would work in Tanzania because according to him there were no economic division into classes which needs party organization to further their interests. He might have been right at that time. However, over the time classes have emerged and consolidated themselves. Some identify themselves no longer with the local masses but with foreign interests. According to Nyerere:

"Some of our people identify their own personal interests with the existing neo-colonial situation. They are to be found among the local agents of foreign capitalists and among the local capitalists who have developed in the shadow of large foreign enterprises. " ${ }^{62}$

Recent research has managed to concretely identify the classes in Tanzania. ${ }^{63}$ Therefore, in our struggle for justice we have to identify our issues more clearly. It is fundamentally wrong to identify problems in terms of institutions e.g. the party v. government or parliament. The important question is which classes control these institution? Professor Fimbo summarizes this point articulately:

"Whether or not the government is subordinate to the party is a non issue. The primary question is what class controls the party and/or government? An analysis of the class nature in the Tanzanian Society has been undertaken and it is there stated that it is the Petty-bourgeoisie that dominates both the party and the government. $1{ }^{64}$ We concur. The struggle for justice and for the Bill of Rights is a struggle between this class which is in minority and the mass of the people of Tanzania made of workers and peasants who had never had the opportunity to say what type of society they would like to live in. Everything has always been pre-prepared ostensibly for and on their behalf but without their consent.

62 This speech made by the then President of Tanzania at Ibadan University in Nigeria in 1976 is quoted by Omwony-Otwok. "Who is to lead the Popular Anti-Imperialist Revolution in Africa? In Refetation of Issa G. Shivji's Petty-Bourgeois Neo-Marxist Line" in Tandon, Yash, (ed.) Debate on Class, State and Imperialism. Dar es Salaam: Tanzania Publishing House 1982 p.186 at p. 188.

63 See Shioji, Issa G., Class Struggles in Tanzania, London: Heinemann, 1975.

64 See Fimbo, G. Mgongo, "Land, Socialism and the Law in Tanzania" in Ruhumbika, G. (ed.) Toward Ujamaa - 20 Years of Tanu Leadership. Nairobi: East African Literature Bureau, 1974, also reproduced in Eastern Africa Law Review volume 6 No. 3 (1973) p. 215. 